\title{
実物大実験に基づく木造軸組工法住宅の静的動的復元力特性に関する研究 STUDY ON THE STATIC AND DYNAMIC HYSTERESIS CHARACTERISTICS OF WOOD-FRAMED RESIDENTIAL STRUCTURES BY FULL-SCALE TESTS
}

\author{
綿引誠*1, 町田健一*1, 大橋好光*2, 坂本 功*3 \\ Makoto WATAHIKI, Kenichi MACHIDA, Yoshimitsu OHASHI \\ and Isao SAKAMOTO
}

\begin{abstract}
To clear the static and dynamic hysteresis characteristics of wood-framed residential structures, shaking table tests and static loading tests using various walls which composes wooden house, and full-scale shaking table test and static loading test on the same plan. Comparing the load-deformation relation of the full-scale tests, the dynamic test exceeded the static test in the load at the same deformation angle, and the dynamic test showed $119 \%-123 \%$ of the static test until $1 / 200$ rad on the 1 st floor. The load-carrying capacity, which was estimated by summing of static hysteresis characteristics in walls, was checked with the result of the full-scale dynamic test. By summing all wall elements, which were thought as the surplus force, the stiffness was estimated in about $90 \%$ of precision until $1 / 75$ rad.but the maximum load and toughness weren't evaluated in the larger deformed range. As for the sharing rate of the horizontal-force of braces of the full-scale tests, it was about $20-50 \%$ in the static test and about $30-45 \%$ in the dynamic test. It's considered that the effect of wall elements except braces worked in the dynamic tests more than the static tests.
\end{abstract}

Keywords : Post and Beam Construction, Wooden House, Full-scale Experiment

Hysteresis characteristics, Seismic Performance

軸組構造，木造住宅，実大実験，復元力特性，耐震性能

\section{1.はじめに}

建築基準法の性能規定化や、住宅の品質確保の促進等に関する法 律を背景として、住宅はより適切な性能設計が求められる時代とな った。その一方で、木造住宅の設計では未だ壁量計算による設計手 法が一般的に広く用いられており、静的加力実験で評価された耐力 壁単体の構造性能に基づいて建物全体の水平抵抗力を規定してい る。しかし、兵庫県南部地震後に数多く行われた木造住宅の実大振

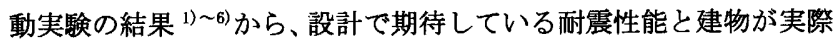
に保有している性能の間に大きな乘離があることが明らかになっ てきた。これは安全性に対する余裕代ではあるが、設計時により正 確な耐震性能を把握できていなければ、真の性能設計・性能表示と は言えない。

そこで、静的な耐力壁単体の構造性能だけではなく、動的な耐力 壁の挙動や、立体的な効果を含む実物大建物の静的動的挙動などそ れぞれの状態での性能を明確にした上で、互いの関連性について把 握することが必要である。既往の研究の中で、壁要素の静的実験、 動的実験を行い、さらに、実物大建物での静的加力実験と振動実験
を同じ仕様の建物で実施して、相互に比較分析したものはでごく僅

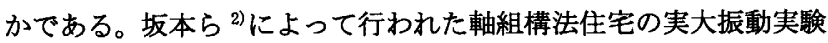
（多度津 $\mathrm{A}$ 棟）では、その後、田中ら そよって静加力実験や仮動 的応答実験、さらに建物を構成している壁単体の実験までもが行わ れているが、実験的な制約もあり、相互の関連性を完全に結論付け るまでには至っていない。

本研究は、実物大建物を構成する壁要素の静的加力実験と振動実 験 ${ }^{8)}$ 、同仕様・同プランで実施した実物大建物の静的加力実験と振 動実験 9)の結果を比較分析し、それぞれの復元力特性について関連 性を述べたものである。図 1 に研究対象とした 4 つの実験の構成を 示す。まず第 2 章では、これらの実験概要を述べる。第 3 章では、 壁要素と実物大建物の静的動的荷重变形関係を比較分析する。第 4 章では、壁の復元力特性の加算則を静的動的データに基づいて検証 する。最後に第 5 章では、主要な耐力要素である筋かいについて、 実物大建物の中での静的動的特性を軸力比較によって分析すると 共に、層せん断力に対寸る水平力負担率について静的動的両方の観 点から考察を行った。
*1 住友林業侏筑波研究所 主任研究貝

*2 武藏工業大学 教授. 工博

*3 東京大学大学院教授・工榑
Researcher, Sumitomo Forestry Co., Ltd.

Prof., Musashi Institute of Technology, Dr. Eng.

Prof., The Univ. of Tokyo, Dr. Eng. 


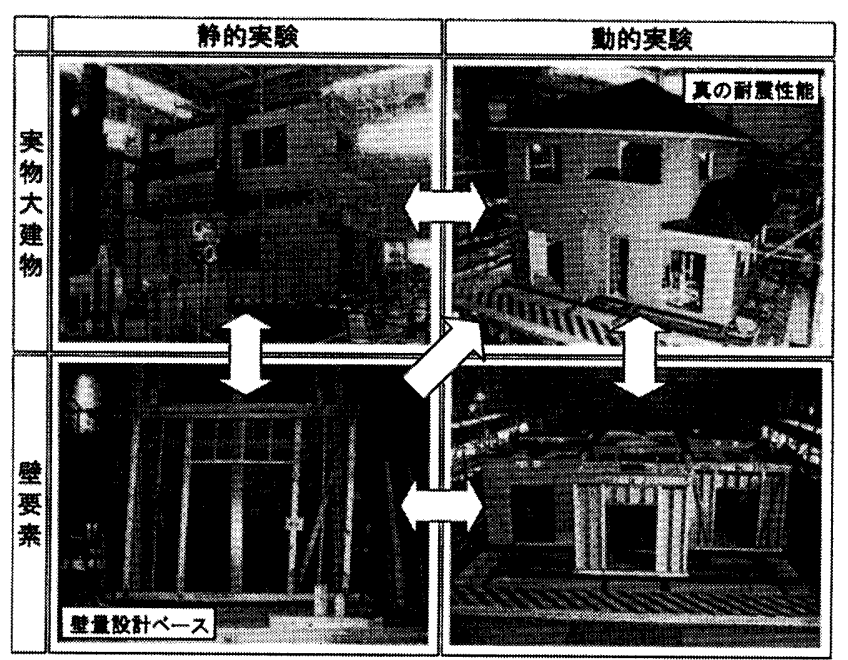

図 1 研究対象実験の構成

表 1 試験体仕様（共通部材）

\begin{tabular}{|c|c|}
\hline 策 & 世青 \\
\hline 土点 & EW-ヘ '化' (E85F270), $105 \times 105$ \\
\hline Fa! & 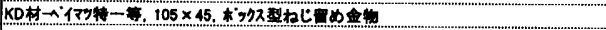 \\
\hline 住 & EW-SPF (E85F300), $105 \times 105($ RAI: 120 M $)$ \\
\hline ZL柱 & EW-A'177(E120F330), $120 \times 120$ \\
\hline 2FG星 & 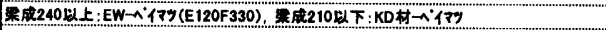 \\
\hline 小星果 & 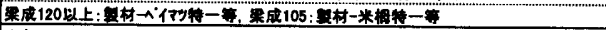 \\
\hline T/A-末：Mr & 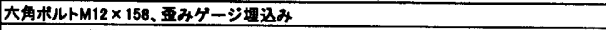 \\
\hline 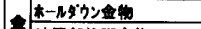 & 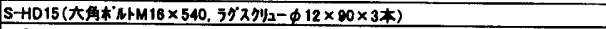 \\
\hline 外周部在閏金韵 & 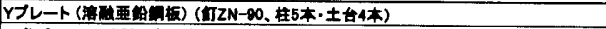 \\
\hline 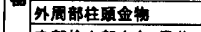 & 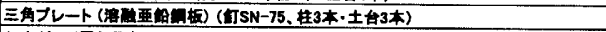 \\
\hline 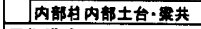 & 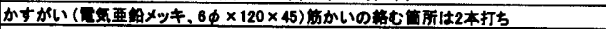 \\
\hline 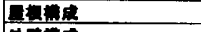 & 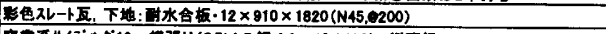 \\
\hline 外是青诚 & 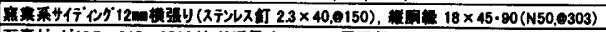 \\
\hline 内量贯成 & 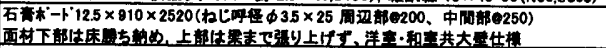 \\
\hline Einger & 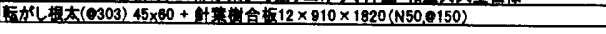 \\
\hline
\end{tabular}

\section{2. 比慗対象実跙概要}

壁と実物大建物を対象として、同じ仕様、同じ形状・プランによ る静的加力実験（静的実験）と振動台実験（動的実験）を実施 ${ }^{8) 9}$ した。共通する主な部材の仕様を表 1 に示す。

\section{1 壁の静的動的実跧の概要}

比較対象とした壁試験体は、壁要素と開口種類を組み合わせた 12 種類である。試験体の高さは $3055 \mathrm{~mm}$ で実物大建物と同寸とし、幅は 2 間 $(3640 \mathrm{~mm})$ の大きさで中央 1 間に開口部を設けられるようにした。 壁要素は 3 尺筋かい $45 \times 105$ (B)、石衰ボード $12.5 \mathrm{~mm}(\mathrm{G}) 、$ サイディ ング $12 \mathrm{~mm}$ (S)の 3 種類で、それぞれを組み合わせた複合体 2 種類 (BG, BGS) も用意した。軸組フレームの特性を確認するために軸組 (F) のみ の試験も行なった。なお、石高ボードは実物大建物と同様に横架材 には留めつけない淮耐力壁仕様である。開口種類は掃出開口 (Z1)、 空形開口 (Z2)、全開口 (Z3)、無開口 (Z4)の 4 種類である。

静的実験は、試験体両端の柱脚と柱頭にホールダウン金物に設置 した柱脚固定の無載荷方式で正負交番繰り返し加力を行った。動的 実験は、振動台上に静的実験と同じ壁試験体を並行に並べ、上部を 剛な床でつなぎ直交壁を合板で固めて箱形の試験体とし、錘を载せ て兵庫県南部地震の神戸海洋気象台波（JMA-KOBE、NS 成分）による 水平一方向加振を行った。振動テーブル上で最大 7 体の試験体を同 時に加振した。1 回の加振では限界性能に至らないものもあったた め、続けて 2 回の加振を行なった。壁の動的実験の試験体図を図 2 示す。
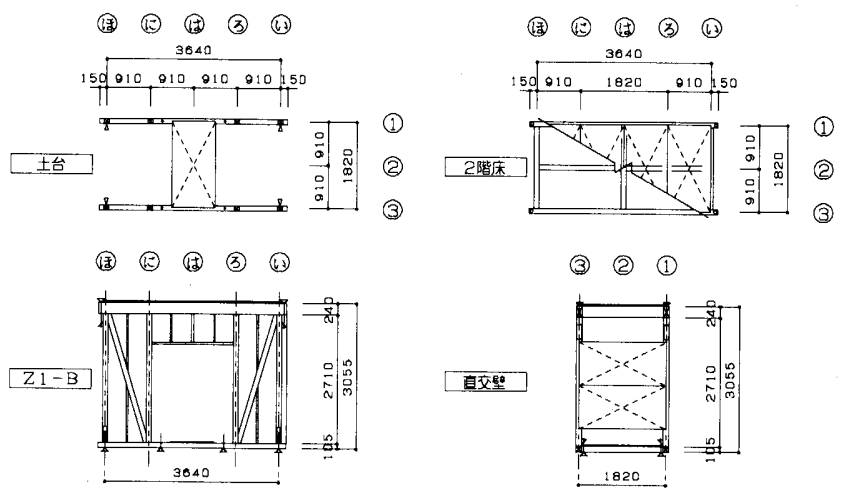

図 2 壁の動的実験の試験体図

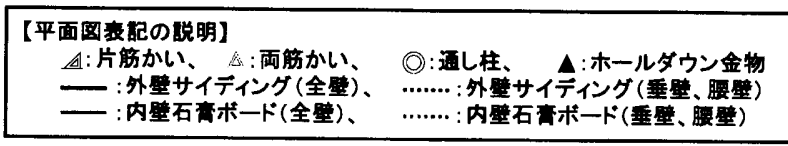

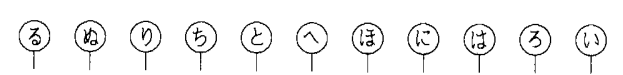

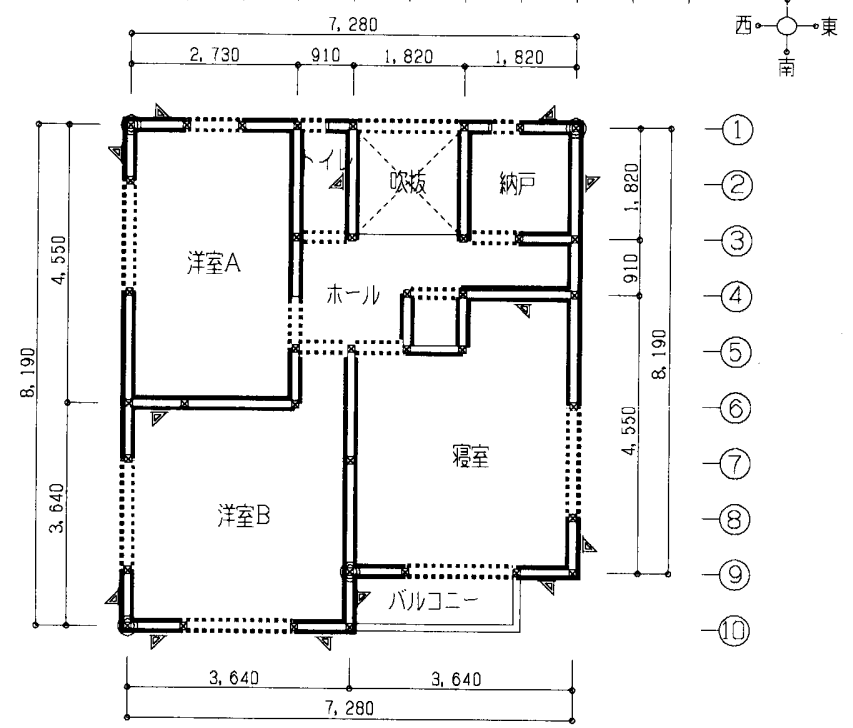

2嘴平面图

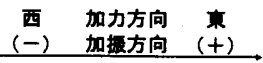

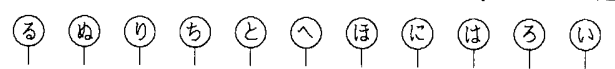

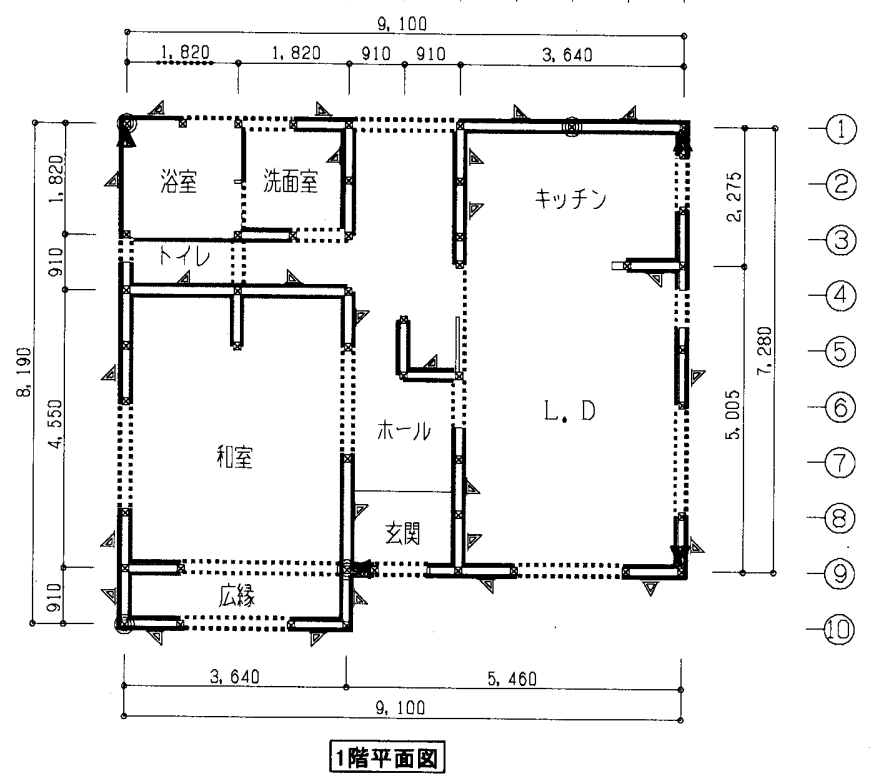

図 3 試験体平面図 


\section{2 実物大建物の静的動的実検の概要}

建物は在来軸組工法による一部下屋付き 2 階建て住宅で、床面積 は 1 階 $69.6 \mathrm{~m}^{2} 、 2$ 階 $56.3 \mathrm{~m}^{2}$ 、延べ床面積 $125.9 \mathrm{~m}^{2}$ である。試験体 の平面図を図 3 に示す。実験では通常の基礎の代わりに $\mathrm{H}$ 型鎆を使 用し、これにアンカーボルトとホールダウンボルトで建物を緊結し た。また、軸組接合部は金融公庫仕様書に順ずる接合金物で補強し た。屋根は寄棟の彩色スレート瓦莫きで、外壁には空業系サイディ ングを横張りした。内壁は石亮ボード張りで、休は根太十合板 $12 \mathrm{~mm} 、$ 一部、天井を施工しない代わりに重りを積載した。耐力壁は筋かい で、施行令 46 条の必要壁量に対し、存在壁量は加力加振方向 1 階が 1.44、同 2 階が 1.72 の充足率である。建物の偏心率は 1 階が 0.04 〜 0.14、2 階が 0.11 であり、比較的バランスよい配置となっている。 また、2 階床には $600 \mathrm{~N} / \mathrm{m}^{2}$ の地震用䅡載荷重を載せており、試験体 の重量は 1 階が $112 \mathrm{kN} 、 2$ 階が $65 \mathrm{kN}$ 、合計 $177 \mathrm{kN}$ である。

静的実験は、建物の東西方向を軸とした一方向押し引き交番加力 で行った。各階の胴差し・桁梁にH形龬を取り付け、それぞれを PC 鋼棒にて締め付けた後、H形鋼を介し反力タワーに取り付けた油圧 ジャッキで加力した。高さ方向の加力位置は、施行令 88 条の層せん 断力分布係数 $\mathrm{Ai}$ を用いて求めた各階の地震力の比率により算出し、 水平方向の加力位置は重心とした。なお、実験終了後に確認したと ころ、加力治具の高さが設計よりも $454 \mathrm{~mm}$ 低い位置に取り付けられ ており、2 階への外力が想定の $68 \%$ しか入力できていなかった。加 カサイクルは 1 階の層間変形角を制御として $\pm 1 / 500 \mathrm{rad} . \rightarrow \pm$ $1 / 250 \mathrm{rad} . \rightarrow \pm 1 / 120 \mathrm{rad}$. ( 2 回絽り返し) $\rightarrow \pm 1 / 60 \mathrm{rad} . \rightarrow \pm 1 / 30 \mathrm{rad}$. の順で行った。最終的には東方向に装置の限界まで加力し、1 階見 かけの変形角 $1 / 19 \mathrm{rad}$. で終了した。計測はジャッキに設置したロー ドセルにより建物に加えた荷重を測定し、試験体には層閒変位計測 用、土台・柱脚・柱頭・筋かいの接合部計測用の変位計を設置した。 また、柱・筋かいには下から $1 / 4$ の高さの両面に歪ゲージを取付け、 アンカーボルトとホールダウンボルトには歪みグージ埋め込むこと で、軸力を測定した。なお、計測歪みから軸力への換算は、実験終 了後に歪ゲージを取り付けたままで部材を取り出し、それぞれの引 張試験を行うことで直接的に求めた。

動的実験は建物の東西方向を軸とした水平一方向加振で行った。 入力地震動は壁の動的実験と同じ神戸海洋気象台波（JMA-KOBE、NS 成分）を基本に、最大加速度 $818 \mathrm{gal}$ を 1000gal に基準化した波形を 目標波 (以下 JMA $1000 \mathrm{gal}$ と呼ぶ) とした。フェーズ 1 で実際に入力 した地震波は、最大加速度 1096gal、最大速度 92kine、最大変位 $18.1 \mathrm{~cm}$ が振動台上で記録された。実験は試験体の損傷状態により、 フェーズ $1 \sim 3$ の各段階に分けて行った。フェーズ 1 は、損傷の全 くない試験体に対し JMA1000gal を入力した。フェーズ2は、フェ 一ズ 1 の履歴をそのままに試験体に何も手を加えない状態で再度 JMA1000gal を入力した。フェーズ 3 は、破断した筋かい及び 1 階加 振方向の石高ボード全てを張り替えた試験体に対し JMA1000gal を 入力した。なお、以降の比較検討ではフェーズ 1,2 の結果のみを 用いている。また、各部の軸力は静的実験と同様の方法で計測を行 った。

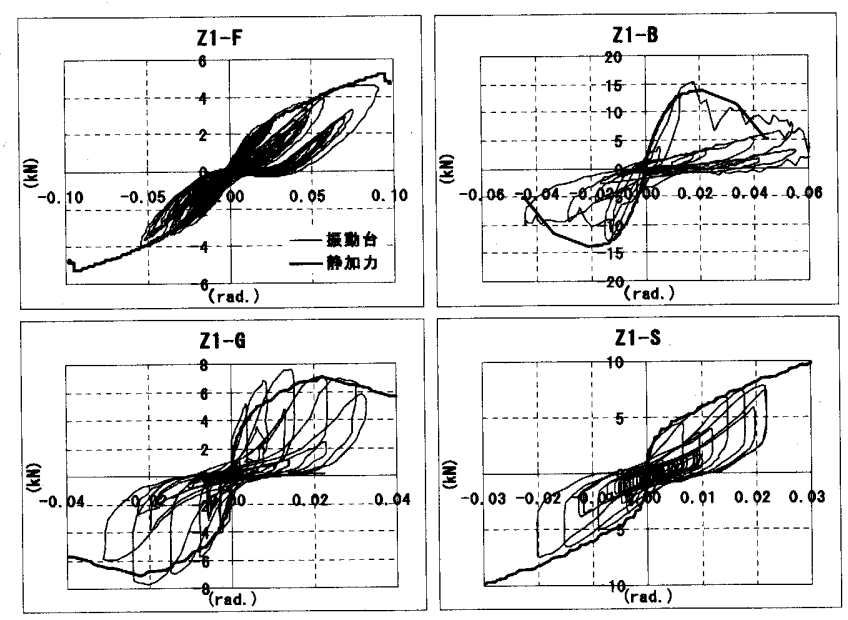

図 4 掃出開口 (21)の単体要素別比較

\section{3. 復元力特性の静的動的比較}

\section{1 晴実跧の復元力特性の静的動的比較}

壁の静的実験と動的実験の結果を比較して、壁の復元力特性につ いて静的動的特性を分析した。なお、動的実験の荷重は壁の振動台 実験の梁上応答加速度と各試験体の質量（柱高さ $1 / 2$ より上、重り 含む）の積から推定した。その際、加速度データは両側の壁の平均 值を用い、荷重は静的実験との比較のため単体の 2 間壁に換算、す なわち箱形試験体実験值の $1 / 2$ とした。

\section{1 . 1 復元力特性要素別比㜞}

図 4 に、単体要素の静的実験の包絡線と、動的実験の荷重-変形関 㐿の比較を示す。いずれも掃出開口（Z1）付きのものである。なお、 静的実験の変形 $(-)$ 側の包絡線は変形 $(+)$ 側の包絡線の符号を逆転し たものである。

・ 軸組 $(F)$ の荷重一変形関係は、静的動的にほとんど変わらない。

・ 筋かい(B) は初期の段階ではほとんど同じ曲線を描いているが、 動的実験の方が若干小さい変形で最大荷重をむかえ、その後の 荷重低下も急激な傾向にある。筋かい(B) は動的に評価するとよ り勒性がそしくなる。

・石衰ボード (G)は、動的実験の方が静的実験よりも 2 割程剛性 が高く、最大荷重もより小さな変形で迎える。ただし、それ以 降の大変形領域では粘り強い挙動を示し大きな差はない。同一 変形に至る綝り返し回数は約 2 倍動的実験の方が多いが、初期 の段階から動的荷重が高い值を示し、繰り返し回数が影響した ものではないと考えられる。

・ サイディング (S) は 1/50rad. までの範囲でほとんど同じ挙動を 示している。初期剛性が非常に高く、塑性化しても安定して荷 重が伸びるは静的も動的も変わらない。ただし、動的実験では これ以上の変形でのデータが取得できていないため、最大荷重 や勒性については評価できなかった。

\section{1. 2 開口種類別比㜞}

図 5 に筋かい十石高ボード(BG)について、図 6 に筋かい十石高ボ 一ド+サイディング(BGS) について、静的実験の包絡線と動的実験 


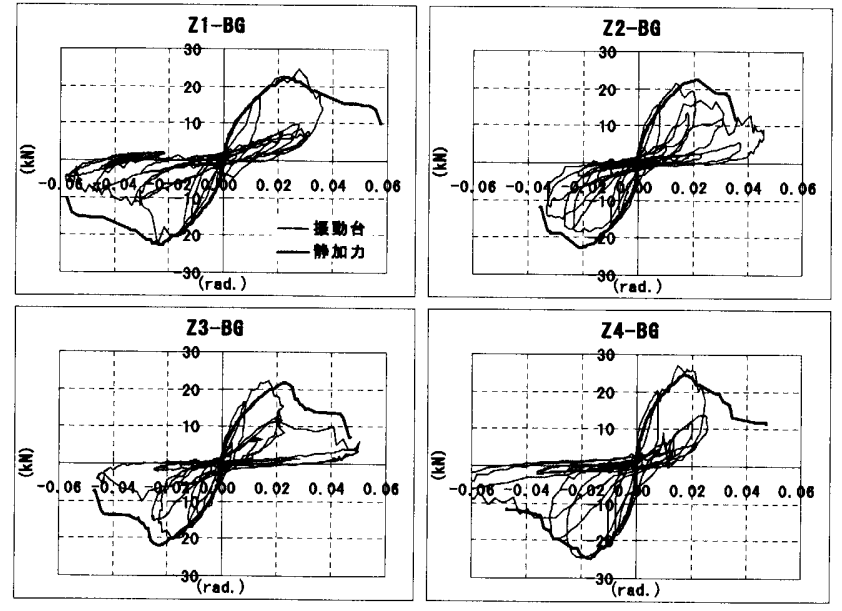

図 5 矨かい十石亳ボード(BG)の開口種類別比較

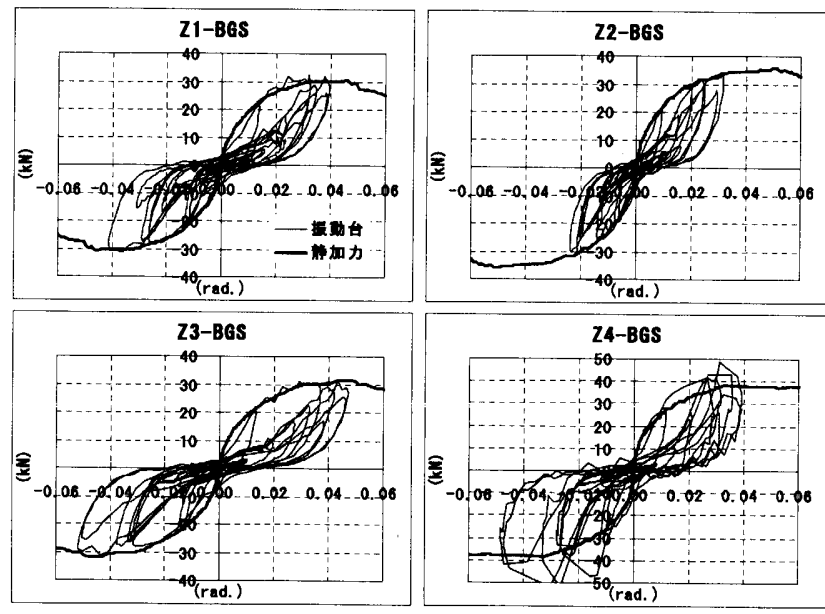

図 6 笳かい十石䨋ボード+サイディング(BGS)の開口種類別比較

の荷重一変形関係の比較を示す。

- 筋かい十石亮ボード (BG) は、動的実験の方が静的実験よりも若 干高い荷重を示すものもあり、動的ではより小さい変形で最大 荷重をむかえる傾向がある。

・ 筋かい十石衰ボード+サイディング(BGS)でも同様に、動的実 験の方が静的実験よりも若干高い荷重を示す傾向がある。特に 無開口（Z4）にその傾向が大きいのは、石亳ボードの占める割 合が多く、その動的特性が顕著に表れたものと考えられる。

\section{2 実物大建物の復元力特性の静的動的比較}

実物大建物の静的実験と動的実験の結果を比較し、木造軸組工法 住宅の復元力特性について静的動的特性を分析した。

静的実験と動的実験（フエーズ 1 とフェーズ 2）の 1 階の荷重一変形関 係を図 7 に、2 階の荷重一変形関係を図 8 に、それぞれの代表包絡 線を図 9 と図 10 に示す。また、代表包絡線から取り出した特定変 形角時荷重を表 2 に示し、静的荷重と動的荷重の比率を記載した。 荷重一変形関係は、静的にも動的にもほぼ同じような性状を示し ているが、特定変形角の荷重は動的実験が上回っている。壁の場合 と同様に、同一変形に至る繰り返し回数は約 2 倍動的実験の方が多

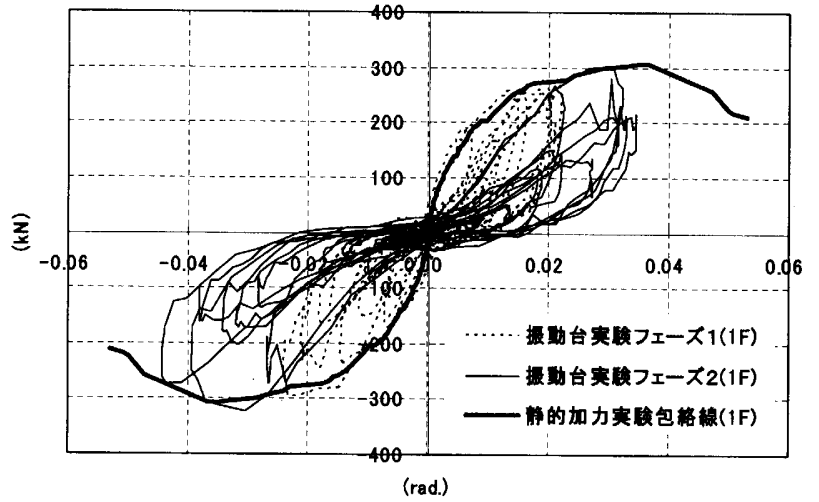

図 7 静的加力実験と振動台実験の 1 階の荷重一変形関保

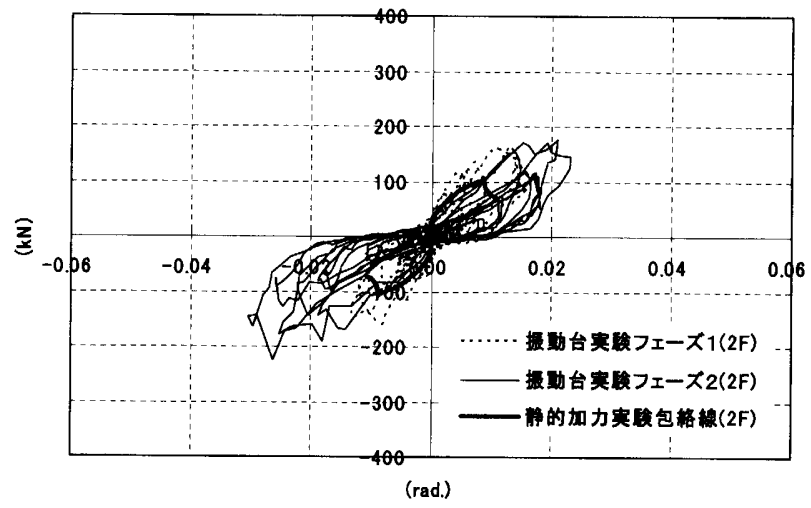

図 8 静的加力実験と振動台実験の 2 階の荷重一変形関倸

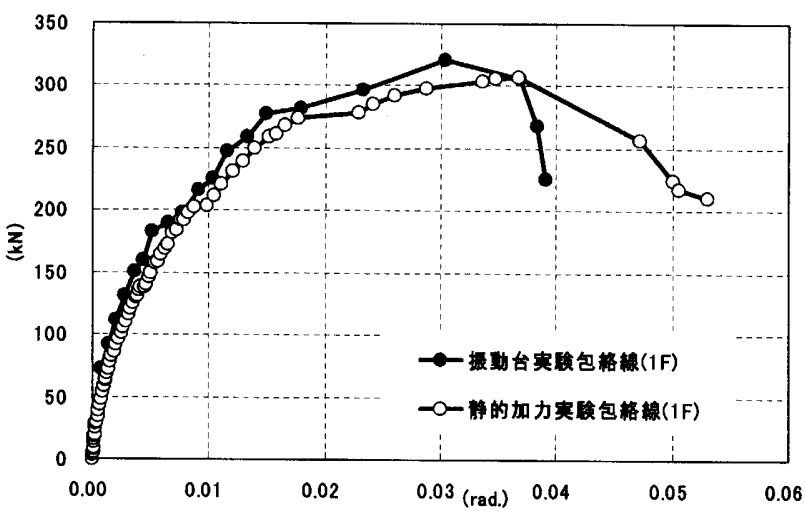

図 9 静的加力実験と振動台実験の 1 階の代表包絡線

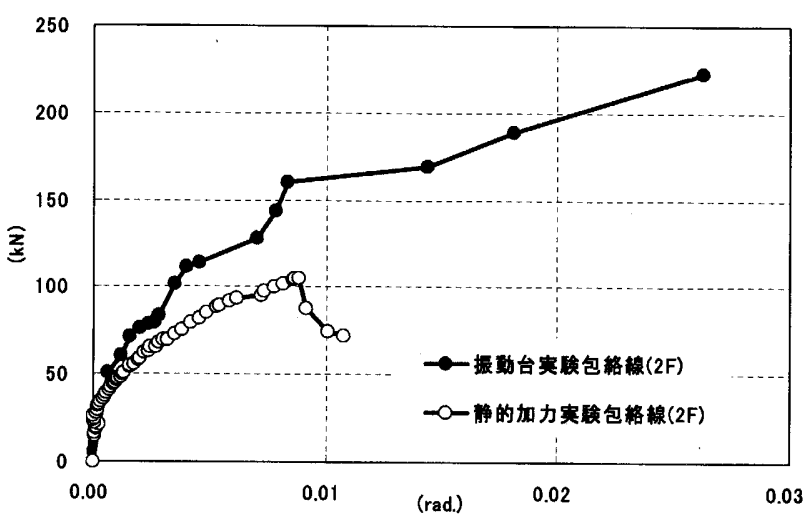

図 10 静的加力実験と振動台実験の 1 階の代表包絡線

※図 7〜10の振動台実験の荷重は同じ実験を示した参考文献 9)の值 より小さくなっている。これは建物質量を詳細に再計算した結果である。 
表 2 特定変形角時荷重の比較

\begin{tabular}{|c|c|c|c|c|c|c|c|c|c|c|c|}
\hline \multirow{2}{*}{\multicolumn{2}{|c|}{ 特定交形角時荷再 }} & \multicolumn{10}{|c|}{1 㜆变形角（rad.) } \\
\hline & & $1 / 600$ & $1 / 450$ & $1 / 300$ & $1 / 200$ & $1 / 150$ & $1 / 120$ & $1 / 100$ & $1 / 75$ & $1 / 50$ & $1 / 30$ \\
\hline \multirow{3}{*}{ if } & 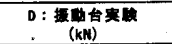 & 101 & 118 & 145 & 179 & 191 & 207 & 223 & 259 & 288 & 315 \\
\hline & 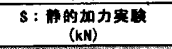 & 83 & 95 & 122 & 148 & 177 & 189 & 206 & 244 & 276 & 304 \\
\hline & 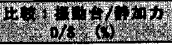 & 123 & $12 x$ & 110 & $121 \%$ & $108 \mathrm{~s}$ & 1045 & 1008 & 1004 & $10 \%$ & 104 \\
\hline \multirow{3}{*}{$2 \mathrm{~F}$} & $D:{ }_{(\mathrm{kN})}$ & 73 & 78 & 98 & 117 & 127 & 160 & 183 & 168 & 197 & \\
\hline & 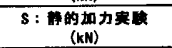 & 55 & 63 & 71 & 87 & 95 & 103 & & & & \\
\hline & 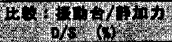 & thin & 1258. & 137 & 1368 & $13 t$ & 168 & & & & \\
\hline
\end{tabular}

いが、初期の段階から動的荷重が高い值を示し、繰り返し回数が影 響したものではないと考えられる。1階では $1 / 200 \mathrm{rad}$ までの比率 が高く、静的実験の $119 \%$ 123\%を示した。それ以降は徐々に静的実 験との差は小さくなり $104 \%$ 109\%の範囲で推移した。2 階での静的 実験に対する動的実験の荷重比は $125 \%$ 155\%とより高い値を示し ている。前節において、「石衰ボード (G)は、振動台実験の方が静的 加力実験よりも 2 割程剛性が高く、最大荷重もより小さな変形でむ かえる。」とを示した。実物大建物において静的荷重よりも動的荷 重が高くなるのもこの石高ボードによる効果が大きいと考えられる。 2 階でより顕著に荷重比があがっているが、これは壁要素の中に占 める石亮ボードの割合が 1 階よりも 2 階の方が大きいことが要因と して挙げられる。このように建物を構成する壁要素の種類と構成比 率によって、静的荷重と動的荷重の比率は変化するものと考えられ る。

\section{4. 壁の復元力特性の加算則における静的動的比较}

\section{1 壁実跧による加算則の検証}

壁の静的実験と動的実験の特定変形角の荷重値を用いて、各単体 要素の荷重一変形角モデル曲線を足しあわせ、複合要素の実験值と の照合を行った。静的、動的の両面から壁の復元力特性の加算則に ついて検証する。

4. 1 . 1 筋かいと石青ボードの加算 $(B+G)$

能かいと石育ボード $(B+G)$ の静的動的復元力特性の加算則の検証 結果を図 11 に重ねて示す。なお、加算の際には軸組 $(F)$ の荷重が重 ならない様にそれぞれの加算值から重複分を差し引いた。図中記号 は加算した要素と差し引いた軸組 (F)の数量を示している。

- 動的壁加算值は剛性を実際よりも大きく見積もり過ぎる傾向 があり、むしろ静的壁加算值の方が複合体実験值との適合度は 高い。

単体筋かい壁 $(Z 1-B)$ は複合体実験値 (Z1-BG) よりも小さい変形 で座屈によって荷重低下を起こすため、最大荷重や勒性を評価 することはできない。これは静的にも動的にも同じ性状である。

4. 1. 2 筋かいと石费ボードとサイディングの加算 $(B+G+S)$

筋かいと石亳ボードとサイディング $(\mathrm{B}+\mathrm{G}+\mathrm{S})$ の静的動的復元力特 性の加算則の検証結果を図 12 に重ねて示す。

・動的壁加算值は剖性を実際よりも大きく見積もり過ぎる傾向

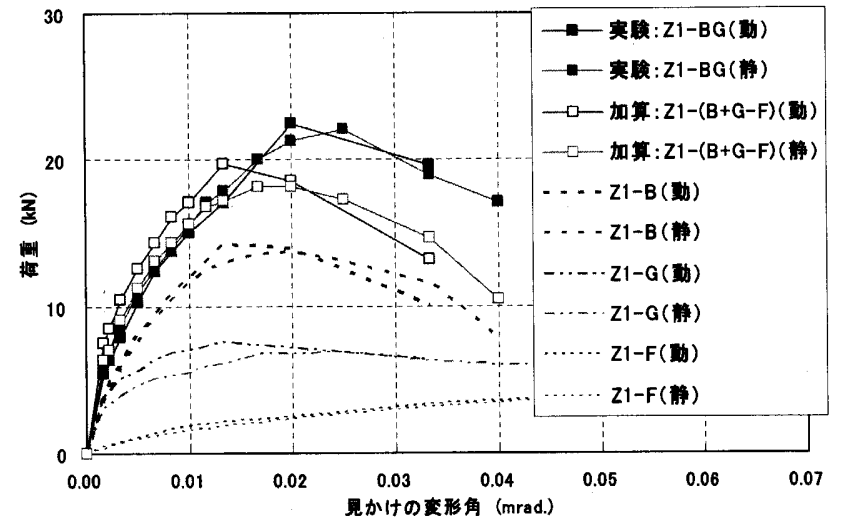

図 11 静的動的復元力特性の加算則の検証 $(B+G-F)$

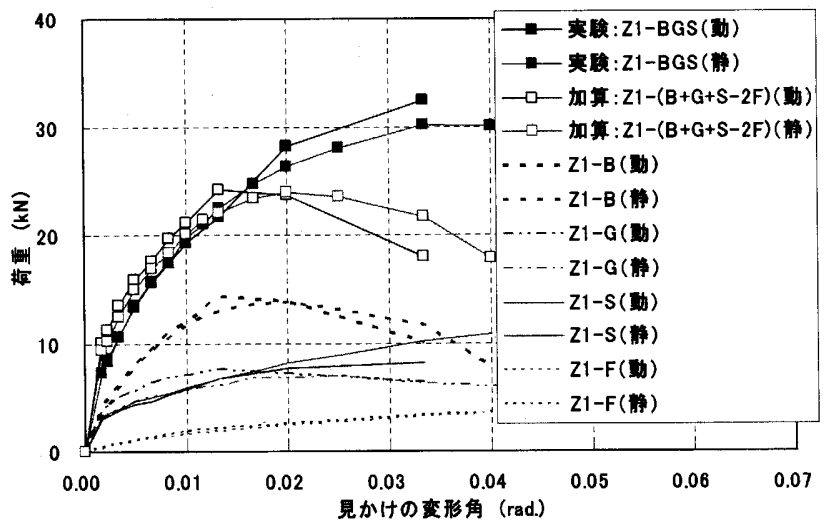

図 12 静的動的復元力特性の加算則の検証 $(B+G+S-2 F)$

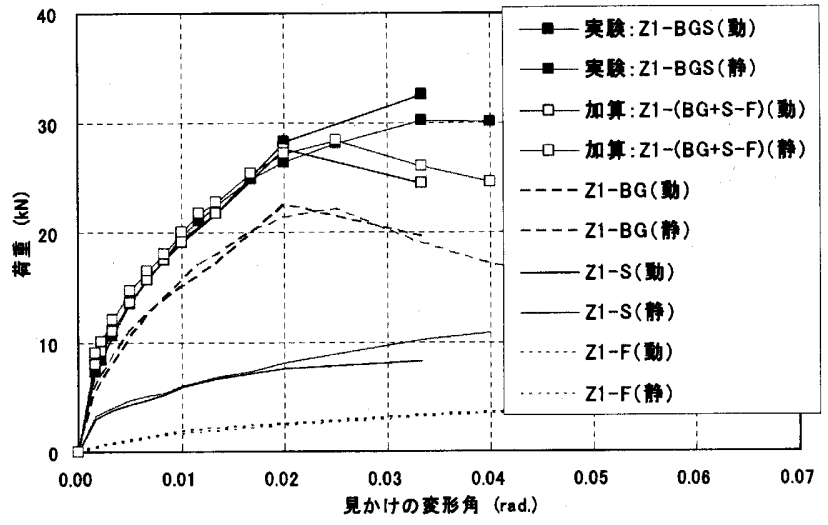

図 13 静的動的復元力特性の加算則の検証 $(\mathrm{BG}+\mathrm{S}-\mathrm{F})$

があり、むしろ静的壁加算値の方が複合体実験值との適合度は 高い。

- 単体筋かい壁 $(\mathrm{Z} 1-\mathrm{B})$ は複合体実験値 (Z1-BGS) よりも小さい変 形で座屈によって荷重低下を起こすため、最大荷重や勒性を評 価することはできない。これは静的にも動的にも同じ性状であ る。

・ 全体的に筋かいと石高ボードの加算 $(B+G)$ で示された傾向と 同様である。

4.1.3 笳かい.石青ボードの複合体とサイディングの加算 $(\mathrm{BG}+\mathrm{S})$

筋かい・石弯ボードの複合体とサイディング $(\mathrm{BG}+\mathrm{S})$ の静的動的 
復元力特性の加算則の検証結果を図 13 に重ねて示す。

- 動的壁加算値と静的壁加算值の差は小さく、1/50rad. までの複 合体実験值との適合度は高い。

- 複合体 (Z1-BG) が筋かいの座屈によって復元力特性低下を起こ す大変形領域では、適合度は低くなり、最大荷重や勒性を評価 することはできない。これは静的にも動的にも同じ性状である

・ 複合体 $(Z 1-B G)$ の復元力特性を用いることで、単体加算值より も複合体実験值の性状をよく捉えることができるのは、静的に も動的にも同じである。

\section{2 実物大建物の復元力特性予測法の静的動的比㜞}

現在、木造軸組工法住宅の耐震設計に用いられている壁量計算は、 壁の静的実験の結果に基づいている。しかし、実際、建物が保有す る耐震性能は実物大建物の振動台実験結果が最も的確に表している と言える。そこで、これらの関係を直接的に比較するため、壁の静 的復元力特性の加算による実物大建物の復元力特性の予測結果と、 実物大建物の振動台実験の比較分析を行った。まず、壁の静的実験 の結果を用いて、実物大建物を構成する 3 つの壁要素、B:筋かい、 G:石亮ボード、S:サイディングについて、静的復元力モデルを作成 した。図 14 に示す。モデル曲線悓かけのせん断変形角における 各サイクルの頂点及び、各要素の特性を表すのに十分な特定変形角 時の荷重を取り出し、軸組 $(\mathrm{F})$ の荷重を差し引いて $1 \mathrm{P}(=910 \mathrm{~mm})$ 当た りの特性として求めた。これに各要素の壁長を乗じ、それぞれを加 算することで建物全体の復元力特性予測ができるようにした。

このようにして求めた実物大建物の計算復元力特性を動的実験の 結果と併せて図 15 に示す。「計算 1 」では基本要素である軸組 $(F)$

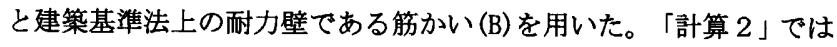

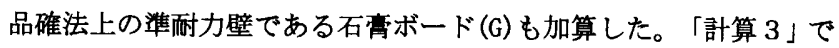
は外壁のサイディング(S)も加えた。さらに「計算 4 」では各要素の 垂壁・腰壁も算入し、実験値との比較を行った。なお、垂壁・腰壁 要素については、全壁に対する垂壁・腰壁の有効高比で実験値を低 減して算入した。

計算 1 が耐力壁である筋かい(B)の静的特性を加算したものであ り、壁量設計の性能值と位置付けられるものである。実際の性能を 表す動的実験值を基準に比較すると、1/75rad.の变形まで 39\%〜 49\% の性能值でしかなく、建物の実際の復元力の半分程度しか評価でき ていない。次に、石费ボードを加算した計算 2 では 73\% 78\%の性能 值となった。通常は算入していないが、真の復元力特性を予測する には非常に大きな影響を与える要素である。計算 3 で外壁のサイデ イング (S)を加えると $81 \%$ 87\%の性能值、さらに計算 4 で各要素の 垂壁・腰壁も見込むことで、87\% 94\%の性能値まで予測できるよう になった。壁の静的復元力特性の加算を詳細に行うことによって、 $1 / 75 \mathrm{rad}$. までの変形の範囲内では実物大建物の復元力特性を 9 割程 度まで予測可能なことが分かった。しかし、その後は実験值が約 1/30rad. まで荷重が上昇しているのに対し、計算值は約 1/60rad. で 最大荷重を迎え、荷重低下が始まっている。つまり、今回の方法に

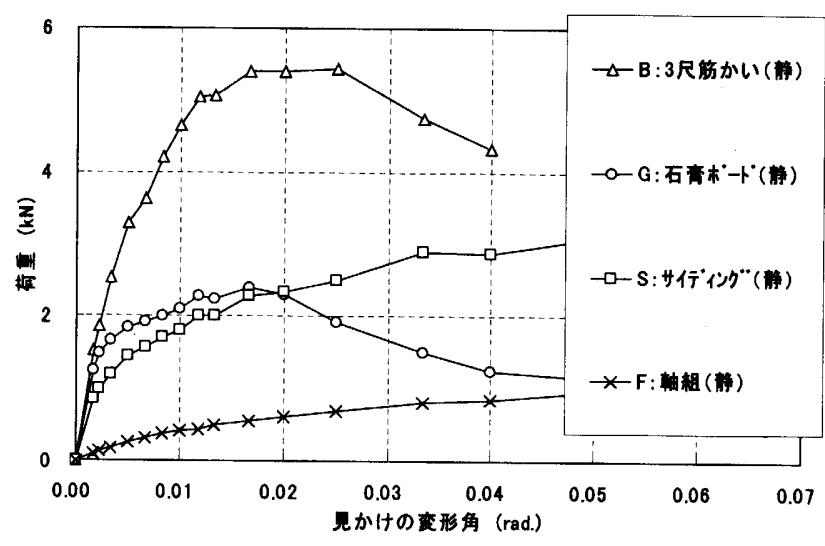

図 14 静的復元力モデル

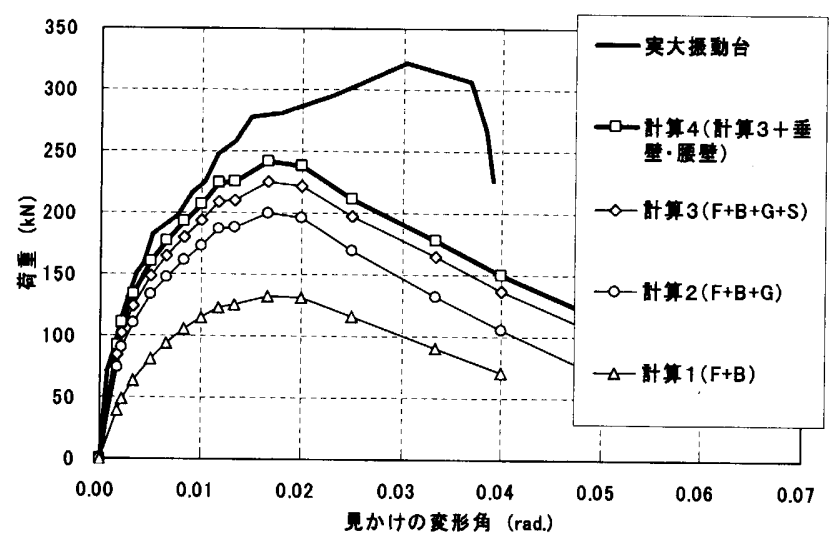

図 15 実物大建物の計算復元力特性と実験結果

よる壁の復元力特性の加算では最大荷重や勒性までは評価すること はできない。変形が進むと実験值との差が大きくなる主な要因とし ては、壁の実験の場合と同様に大変形での筋かいの座屈挙動の違い によるものと考えられる。面材によって拘束された筋かいは座屈举 動が抑えられ、圧縮筇かいとしての復元力が向上し、実際の建物で は最大荷重と靭性が上昇するものと推定できる。

\section{5. 筋かいの静的・動的特性}

\section{1 筇かいに発生する軸力の静的動的比較}

実物大建物の静的実験と動的実験で取得した筋かいの軸力を比 較して、筋かいの実際の建物の中での静的・動的特性を分析した。 1 階筋かいの静的・動的軸力と層間変形角との関倸を筋かいの設置 位置と共に図 16 に示す。竻かい軸力は、赛大実験で計測した歪み と実験後に行った部材引張試験の結果から換算したもので、引張を 正荷重、圧縮を負荷重で示した。また、層間変形角は筋か心取付籄 所近傍の通りのデータを使用した。

筇かいの耐力壁としての静的・動的特性は、「初期の段階の荷重変 形関俰はほとんど同じであるが、動的実験の方が若干小さい変形で 最大荷重をむかえ、その後の荷重低下も急激な傾向にある。筋かい は動的に評価するとより勒性がそしくなる。ということであった。 図 16 に示した筋かい軸力は、実際の建物の中で石亳ボードやサイ 

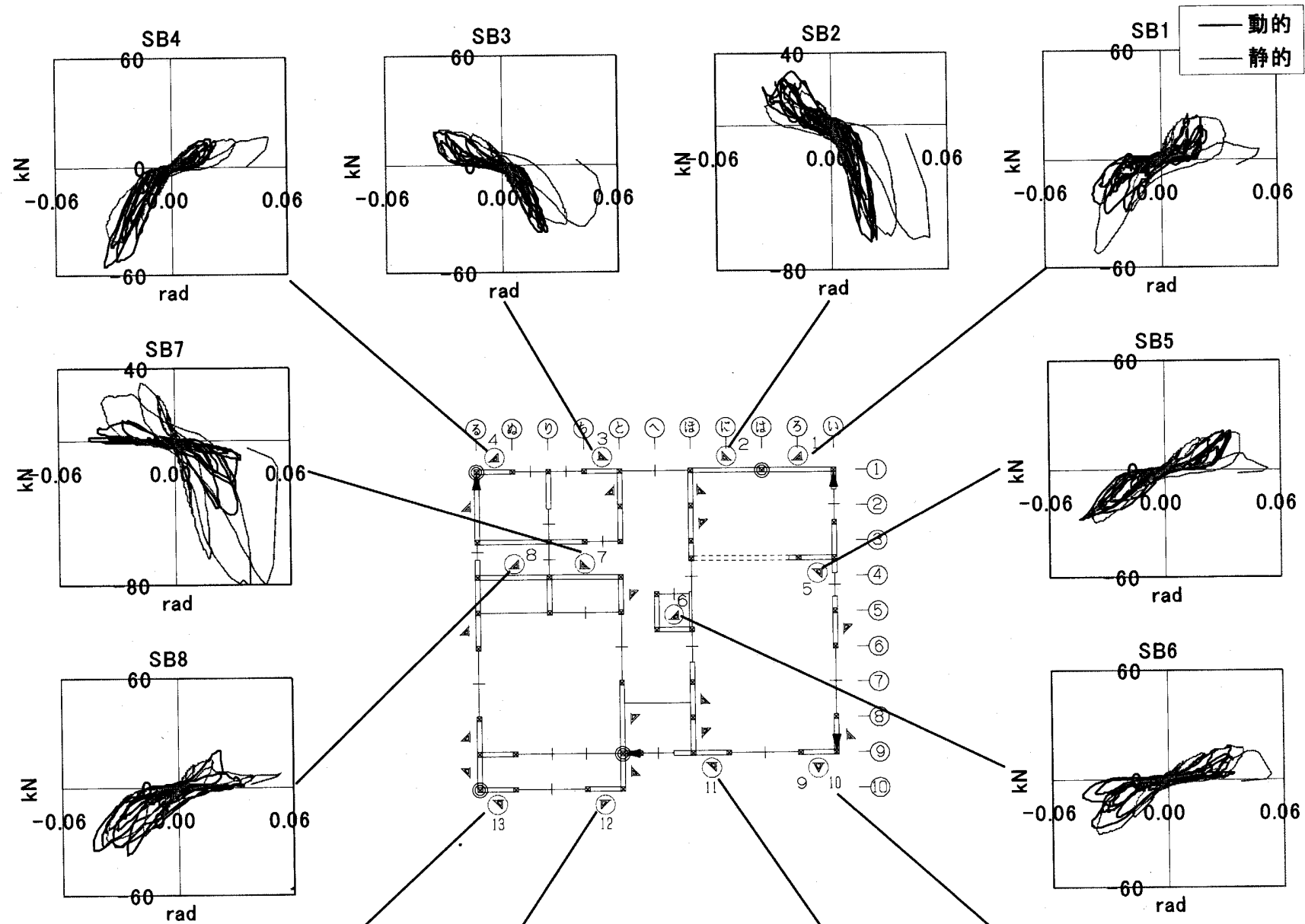

(6)
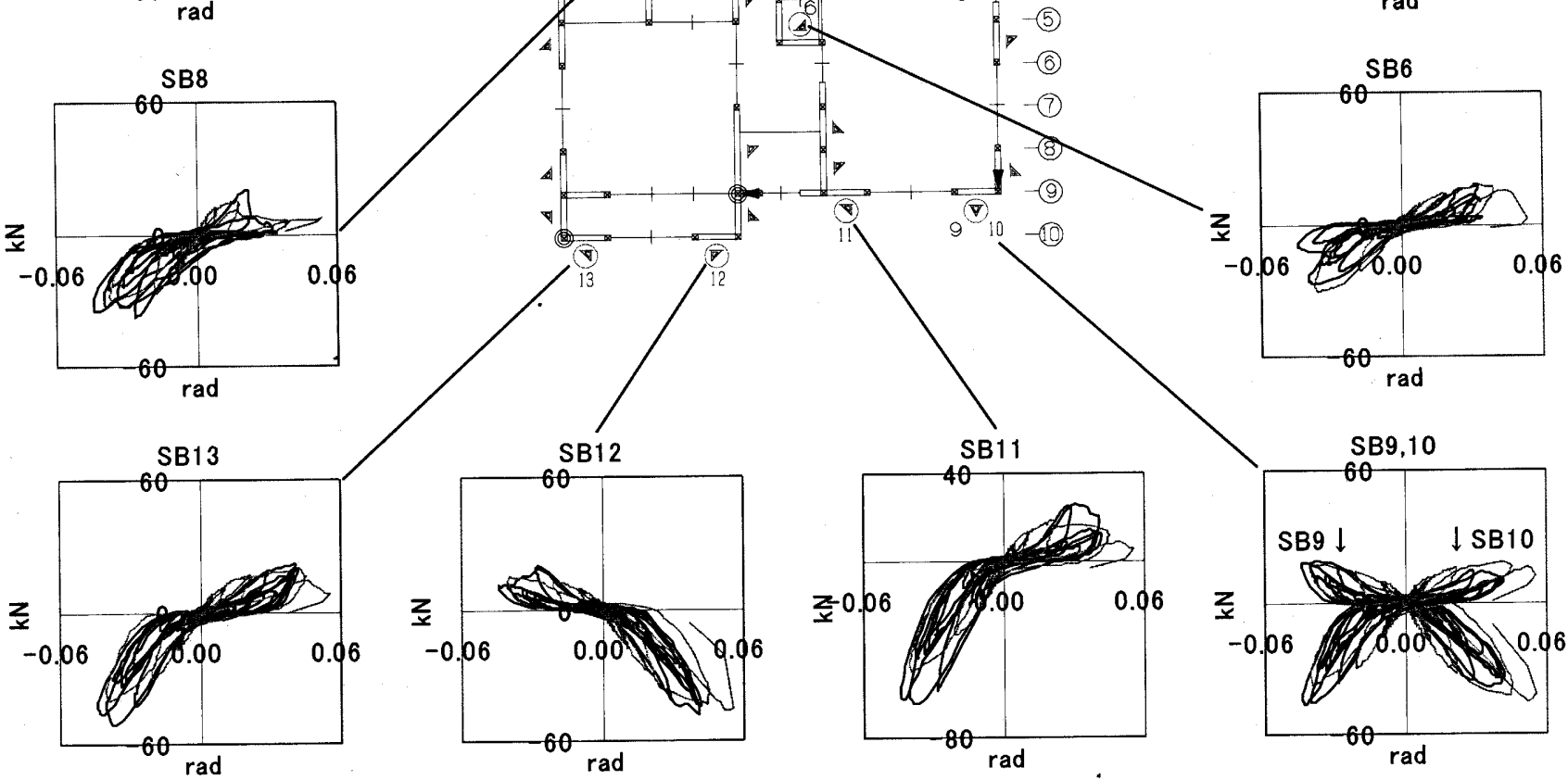

図 16 階筋かい軸力の静的動的比較

ディングによって拘束されている状態での静的・動的特性の比較と なる。

全体的には、同じ変形の範囲では静的な軸力も動的な軸力もほぼ 同じ性状を示しており、概ね単体要素の場合と変わらない結果であ った。特に、筇かい (SB5, 6, 9, 12) 法、スリップ性状や剛性・最大軸 力共、静的にも動的にもほとんど重なっていた。笳かい(SB2, 3) は若 干動的剛性が高く、筋かい(BS4, 8, 10,11,13) は最大荷重を動的の場 合の方が小さい変形で迎えたり、軸力が勝る傾向を示した。その中 で、筋かい(SB1, 7) は静的軸力の方が大きな值を示した。筋かい(SB1) は圧縮側で 1.8 倍の軸力示し、動的には何らかの原因で損傷が生じ 塑性化したものと考えられる。筋かい(SB7) は静的には最大 $81 \mathrm{kN}$ を 示しているが、動的軸力との性状は大幅に違っている。対称に配置
された筋かい(SB8) との性状を比較すると、筋かい(SB7)の静的デー 夕の信頼性には疑問が残る。何れにしても、拘束条件が同じであれ ば、筋かいの静的・動的特性に大きな差はないと言える。これは、 性能評価において、静的実験でも動的実験でもほぼ同等の結果が得 られることを示している。

\section{2 筇かいの水平力負担率の静的動的比較}

筋かいの軸力から加力方向の水平方向成分を算出した。この筋か いの水平方向の負担力を「筋かいの水平負担力」と呼ぶ。また、筋 かいの水平負担力の合計と層せん断力との比を「筋かいの水平力負 担率」と呼ぶ。実物大建物の静的実験と動的実験で求めた筋かいの 水平負担力と水平力負担率の結果を比較分析した。1 階筋かいの水 平負担力について、実物大建物の静的実験と動的実験の比較を図 1 


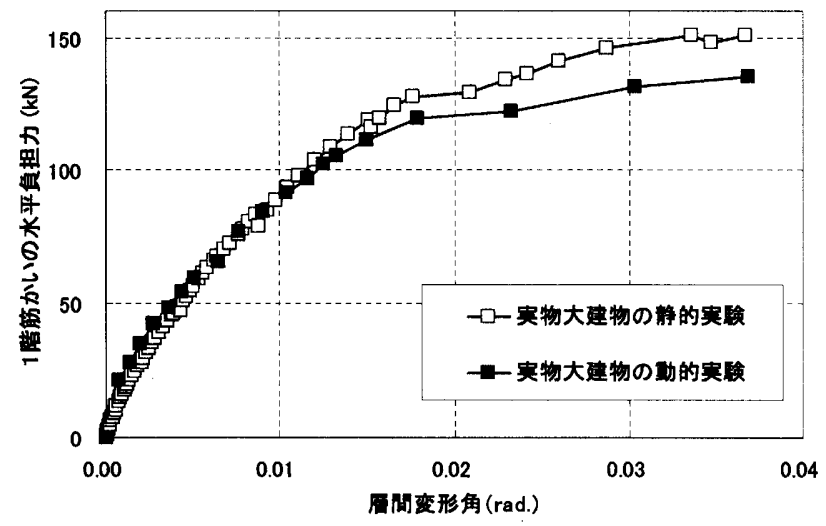

図 17 実物大建物の筋かいの水平負担力（静的動的比較）

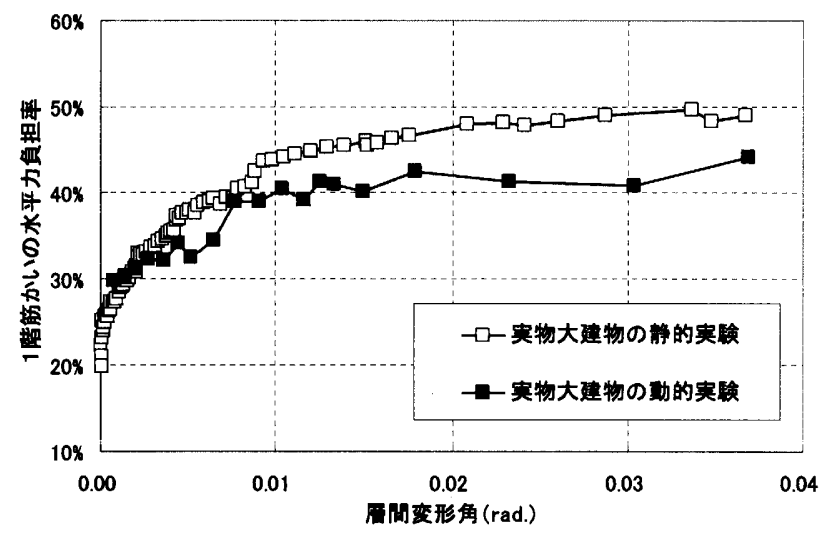

図 18 実物大建物の筋かいの水平力負担率（静的動的比較）

7 に示す。また、1 階筋かいの水平力負担率について同様の比較を 図18に示す。

筋かいの水平負担力は、静的実験も動的実験も変形が進むと共に 増加する傾向にある。また、全体的に初期は動的実験の方が若干大 きいが、変形が大きくなると静的実驗の水平負担力の方が動的実験 の值を 1 割程度上回っている。一方、笳かいの水平力負担率は、静 的実験が 20〜50\%程度で推移するのに対し、動的実験は 30〜 45\%程 度であった。動的実験の方が変動が小さく、全体的に低い割合とな っている。層せん断力の比較では動的実験が静的実験を上回ってい たことから、振動台実験では筋かい以外の効果がより作用している ものと考えられる

\section{6. まとめ}

実物大建物を構成する壁要素の静的加力実験と振動実験、同仕 様・同プランで実施した実物大建物の静的加力実験と振動実験の結 果を比較し、それぞれの関連性を分析した。この比較によって分か ったことを以下にまとめる。

1)壁実験の復元力特性の静的・動的比較から、軸組 (F) とサイディン グ (S)の静的動的特性はほとんど変わらず、筋かい(B)は動的に評
価するとより勒性がそしくなる傾向があり、石衰ボード(G)は動的 剛性が静的剛性より 2 割程が高く、動的にはより小さい変形で最 大荷重をむかえる傾向があることが分かった。

2)実物大建物の荷重一変形関保を比較すると、同じ変形角では動的 実験の荷重が上回り、1 階では $1 / 200 \mathrm{rad}$. まで静的実験の $119 \%$ 123\%を示した。それ以降は徐々に静的実験との差は小さくなった。

3)壁の復元力特性の加算則は動的に剛性を過大評価する傾向があり、 静的加算の方が剛性の適合度は高い。しかし、どちらの場合も最 大耐力や勒性を評価することはできなかった。

4) 壁の静的復元力特性の加算による予測結果と実大建物の動的実験 の結果を照合した。余力として妥当性があると考えられる壁要素 を全て加算することで、1/75rad. 程度までの剛性については 9 割 程度予測可能だが、これを超える大変形領域での最大耐力と勒性 を評価することはできなかった。実際の建物では筋かいの座屈が 拘束され、最大荷重と勒性が向上することが主な要因と考えられ る。

5) 実大実験の筋かいの軸力を静的動的に比較すると、同じ変形の範 囲では静的な軸力も動的な軸力もほほ同じ性状を示した。

6) 実大実験の筋かいの水平力負担率は静的実験が $20 \sim 50 \%$ 程度、動 的実験は 30〜45\%程度であり、動的実験の割合が若干低く筋かい 以外の効果がより作用しているものと考えられる。

\section{考文献}

1）大橋好光, 木村正彦, 高野一義, 川久保政茂, 坂本功：神戸海洋気象台 波 3 次元加振による現代軸組構法木造住宅の実大振動実験（その 1 〜 2 ），日本建築学会関東支部研究報告集，pp. 109-116，1995.03

2）坂本功, 大橋好光, 田中裕樹, 宮澤健二, 角谷智代 : 軸組構法住宅の実 大振動実験（A棟）（その1〜4）, 日本建築学会大会学術講演梗概集（近 畿), pp. 129-136, 1996.09

3）宾澤健二, 北野志乃, 難波蓮太郎, 大橋好光, 坂本功, 田辺英男, 上田 善規，飯鉢整，池本考，栗山留美子：軸組構法住宅の実大振動実験（B 棟）（その $1 \sim 3$ ), 日本建築学会大会学術講演梗概集（近畿）, pp. 137-142, 1996. 09

4）相原庸夫，新居健二，三井信宏，杉本健一，神谷文夫：軸組構法住宅の 実大振動実睁（D棟）（その $1 \sim 5$ ）, 日本建築学会大会学街講演梗概集 (近畿), pp. 143-152, 1996. 09

5）岸川誜史，小原勝彦，宮澤健二：軸組構法住宅の実大振動実験（F棟） (その $1 \sim 2$ ), 日本建築学会大会学術講演梗概集 (近畿), pp. 153-156, 1996.09

6）坂本功, 大橋好光, 木村正彦, 川久保政茂, 宮本善人, 永尾弘行, 小野 塚浩基, 田中裕樹, 铇田文男, 三川卓：J R 鷹取波加振による軸組構法 木造住宅の実大振動実験，（その $1 \sim 8$ ), 日本建築学会大会学術講演梗 概集 (関東), pp. 153-168，1997,09

7）田中裕樹，大橋好光，新居健二：実大実験による木造軸組構法住宅の而 震性に関する研究 (その $1 \sim 2$ ), 日本建築学会大会学術講演梗概集（九 州), pp. 235-238, 1998.09

8）高橋浩一，石山央樹，綿引誠，中野一郎，大橋好光ほ加 4 名：実大実験 に基づく木造軸組構法住宅の耐震性に関する研究 その $1 \sim 5$, 日本建築学 会大会学術講演梗概集（東北） C-1 構造III, pp. 169-178, 2000.9

9）三芳紀美子，大橋好光，高橋浩一，綿引誠，中野一郎，町田健一：軸組 構法住宅用各種壁の静加力試験及び振動台実験その $1 \sim 2$, 日本建築学会 大会学術講演梗概集（関東） C-1 構造III，pp. 199-202，2001.9 